\title{
OSZUSTWO PODATKOWE A PRZESTĘPSTWO OSZUSTWA W PRAWIE POLSKIM I NIEMIECKIM
}

\section{CEL BADAWCZY}

Celem niniejszego artykułu jest ustalenie, czy i w jakim zakresie znamiona przestępstwa oszustwa podatkowego, uregulowanego w prawie polskim w art. 56 $\S 1$ i 2 Kodeksu karnego skarbowego ${ }^{1}$ oraz w prawie niemieckim w art. 370 Ordynacji podatkowej (Abgabenordnung) ${ }^{2}$, pokrywają się ze znamionami klasycznego przestępstwa oszustwa, określonego w art. $286 \S 1$ polskiego k.k. ${ }^{3}$ i w $\S 263$ ust. 1 niemieckiego k.k. ${ }^{4}$, a także jakie wynikają z tego konsekwencje. Autorka przeanalizuje także, czy w którymkolwiek z obu ustawodawstw oraz po spełnieniu jakich przesłanek może zajść pomiędzy tymi normami zbieg rzeczywisty przepisów tudzież tzw. idealny zbieg czynów zabronionych.

\section{UWAGI WSTĘPNE}

Zgodnie $\mathrm{z}$ art. $286 \S 1$ polskiego k.k. przestępstwo oszustwa polega na doprowadzeniu innej osoby do niekorzystnego rozporządzenia mieniem przez wprowadzenie jej w błąd albo wyzyskanie błędu lub niezdolności do należytego pojmowania przedsiębranego działania w celu osiagnięcia korzyści majątkowej. Z kolei z art. $56 \S 1$ k.k.s. wynika, że oszustwo podatkowe sprowadza się do podania nieprawdy lub zatajenia prawdy albo niedopełnienia obowiązku zawiadomienia o zmianie danych, w związku z czym dochodzi do narażenia podatku na uszczuplenie.

Natomiast zgodnie z § 263 ust. 1 niemieckiego k.k. klasyczne przestępstwo oszustwa polega na wyrządzeniu szkody w majątku innej osoby, w celu osiag-

${ }^{1}$ Ustawa z 10 września 1999 r. - Kodeks karny skarbowy, t.jedn.: Dz. U. 2013, poz. 186 ze zm. (dalej jako: k.k.s.).

${ }^{2}$ Ordynacja podatkowa (Abgabenordnung) z 16 marca 1976 r., Federalny Dziennik Ustaw I, s. 613 ze zm. (dalej jako: niemiecka Ordynacja podatkowa).

${ }^{3}$ Ustawa z 6 czerwca 1997 r. - Kodeks karny, Dz. U. 1997, Nr 88, poz. 553 ze zm. (dalej jako: polski k.k.).

${ }^{4}$ Kodeks karny (Strafgesetzbuch) z 15 maja 1971 r., Federalny Dziennik Ustaw 1998 I, s. 3322 ze zm. (dalej jako: niemiecki k.k.). 
nięcia dla siebie lub osoby trzeciej korzyści majątkowej, poprzez wywołanie błędu, spowodowanego podaniem fałszywych faktów albo zniekształceniem lub zatajeniem prawdziwych faktów. Z kolei według art. 370 ust. 1 niemieckiej Ordynacji podatkowej: „Karze pozbawienia wolności do lat 5 albo karze grzywny podlega ten, kto:

1) organom finansowym lub innym organom podaje nieprawdziwe lub niepełne dane co do podatkowo istotnych okoliczności,

2) wbrew obowiązkowi pozostawia w niewiedzy organy podatkowe co do istotnych podatkowo okoliczności,

3) wbrew obowiązkowi nie stosuje znaków uiszczenia podatków lub stempli podatkowych

i poprzez powyższe uszczupla podatki albo uzyskuje dla siebie lub osoby trzeciej nieuzasadnione korzyści podatkowe".

Mając powyższe na uwadze, należy stwierdzić, że już na pierwszy rzut oka widać, iż w opisie przestępstw oszustw podatkowych brakuje wyraźnego wskazania na konieczność wystapienia znamienia „wprowadzenia w błąd” (ewentualnie „wyzyskania błędu”) tudzież „wywołania błędu”, charakterystycznego, a zarazem koniecznego, dla bytu klasycznego oszustwa ${ }^{5}$.

\section{PRZEDMIOT OCHRONY}

Przedmiotem ochrony klasycznego oszustwa - zarówno w prawie polskim, jak i niemieckim - jest mienie. Również w przypadku oszustw podatkowych wskazuje się na mienie jako jedno z dóbr chronionych przepisem $§ 370$ niemieckiej Ordynacji podatkowej oraz art. 56 k.k.s.

Na gruncie prawa polskiego na ogół przyjmuje się, że przedmiotem ochrony art. 56 k.k.s., obok obowiazków podatkowych, jest interes finansowy Skarbu Państwa lub innych uprawnionych podmiotów w zakresie uzyskania kwot należnych tytułem poszczególnych podatków, a tym samym mienie tych podmiotów w zakresie uprawnień wynikających z stosownych regulacji podatkowych $^{6}$. Powyższe koresponduje z treścia art. $114 \S 1$ k.k.s., zgodnie z którym: „Przepisy kodeksu maja ponadto na celu takie ukształtowanie postępowania w sprawach o przestępstwa skarbowe i wykroczenia skarbowe, aby osiagnięte zostały cele tego postępowania w zakresie wyrównania uszczerbku finansowego Skarbu Państwa, jednostki samorządu terytorialnego lub innego uprawnionego podmiotu, spowodowanego takim czynem zabronionym".

Zgodnie natomiast z poglądem dominującym dzisiaj w Niemczech ochronie w $§ 370$ Ordynacji podatkowej podlega interes publiczny w uzyskiwaniu peł-

\footnotetext{
${ }^{5}$ Por. odnośnie do prawa polskiego: postanowienie SN z 26 czerwca 2003 r., V KK 324/2002; odnośnie do prawa niemieckiego: uchwała BGH z 13 stycznia 2010 r., 3 StR 500/09, wistra 2010, 148; uchwała BGH z 27 marca 2012 r., 3 StR 472/11.

${ }^{6}$ P. Kardas, G. Łabuda, Zbieg przepisów kryminalizujacych klasyczne oszustwo oraz oszustwo skarbowe, w: J. Majewski (red.), Zbieg przepisów i zbieg przestępstw w polskim prawie karnym. Materiały II Bielańskiego Kolokwium Karnistycznego, Toruń 2006, s. 113 i n.
} 
nych i zgodnych z prawem wpływów z poszczególnych podatków, a co za tym idzie - roszczenie państwa jako wierzyciela podatkowego o uzyskanie dochodu z każdego pojedynczego podatku w pełnej wysokości i we właściwym czasie ${ }^{7}$. W tym rozumieniu przestępstwo oszustwa podatkowego jest zatem również przestępstwem przeciwko mieniu ${ }^{8}$.

Według innej koncepcji dobrem chronionym w $§ 370$ miałoby być równomierne rozłożenie (podział) ciężarów społecznych. Słusznie jednak zauważa Michael Stahlschmidt, że poprzez przestępstwo uchylania się od opodatkowania majątek uczciwych podatników nie ulega zmniejszeniu, a przynajmniej nie w zauważalnym stopniu. Nie może więc być mowy o jakimkolwiek realnym naruszeniu konstytucyjnej zasady równomiernego nakładania ciężarów podatkowych ${ }^{9}$ przez popełnienie tego przestępstwa.

Reasumujac, należy wskazać, że skoro oszustwo podatkowe służy ochronie mienia, ale wyłącznie publicznego, stanowi ono - podobnie jak klasyczne oszustwo - przestępstwo przeciwko mieniu, tyle tylko, że szczególnego rodzaju, gdyż ogranicza się do ochrony określonej kategorii dóbr ${ }^{10}$.

\section{SKUTEK}

Oszustwo uregulowane w art. $286 \S 1$ polskiego k.k. stanowi przestępstwo materialne. Jego skutkiem jest niekorzystne rozporządzenie mieniem własnym lub cudzym, tzn. że jest to przestępstwo naruszenia dobra prawnego. W polskim orzecznictwie przyjmuje się, że oszustwo polegające na doprowadzeniu do niekorzystnego rozporządzenia mieniem przez wprowadzenie w błąd jest przestępstwem podwójnie skutkowym. Dla odpowiedzialności karnej konieczne jest bowiem ustalenie, że między zachowaniem sprawcy a skutkiem w postaci błędnego wyobrażenia rozporządzającego mieniem o rzeczywistości w części określającej elementy istotne z punktu widzenia decyzji o rozporządzeniu mieniem zachodzi związek przyczynowy, oraz ustalenie, że między zachowaniem sprawcy a rozporządzeniem mieniem zachodzi związek przyczynowy ${ }^{11}$. Jednocześnie warto wskazać, iż na gruncie prawa polskiego powstanie szkody w mieniu nie jest koniecznym warunkiem do przyjęcia, że doszło do niekorzystnego rozporządzenia ${ }^{12}$. Jest to więc pojęcie szersze od terminów „szkoda” i „strata”.

7 BGH, wistra 1996, s. 259 i n.

8 J. Lammerding, R. Hackenbroch, Steuerstrafrecht einschl. Steuerordnungswidrigkeiten und Verfahrensrecht, Achim 1997, s. 36.

${ }_{9}$ M. Stahlschmidt, Steuerstrafrecht. Eine systematische Darstellung mit anschaulichen Beispielen und Abbildungen, Bielefeld 2004, s. 9-10.

${ }_{10}$ Por. B. Hilgers, Täuschung und/oder Unkenntnis der Finanzbehörde - notwendige Voraussetzung der Strafbarkeit wegen Steuerhinterziehung, Köln 1985, s. 39.

11 Por. wyrok SA w Katowicach z 31 sierpnia 2000 r., II Aka 191/00, „Prokuratura i Prawo” 2001, nr 3, poz. 19; wyrok SN z 15 listopada 2002 r., IV KKN 618/99, Lex, nr 75460.

12 Por. wyrok SN z 30 sierpnia 2000 r., V KKN 267/00. 
Również przestępstwo oszustwa uregulowane w $§ 263$ ust. 1 niemieckiego k.k. jest przestępstwem skutkowym naruszenia dobra prawnego ${ }^{13}$. W rozumieniu tego przepisu szkodą jest negatywne saldo pomiędzy wartością mienia przed i po wywołanym błędem rozporządzeniu mieniem przez pokrzywdzonego ${ }^{14}$.

Z kolei w myśl art. $56 \S 1$ k.k.s. do dokonania oszustwa podatkowego konieczne jest wywołanie przez sprawce skutku w postaci narażenia na uszczuplenie danego podatku ${ }^{15}$. Zgodnie z art. $53 \S 28$ k.k.s. „narażenie na uszczuplenie należności publicznoprawnej czynem zabronionym jest to spowodowanie konkretnego niebezpieczeństwa takiego uszczuplenia - co oznacza, że zaistnienie uszczerbku finansowego jest wysoce prawdopodobne, choć nie musi nastapić". Oszustwo podatkowe zalicza się zatem w prawie polskim do przestępstw materialnych z konkretnego narażenia na niebezpieczeństwo.

Oszustwo podatkowe w prawie niemieckim jest także przestępstwem skutkowym (Erfolgsdelikt), tzn. że do jego dokonania, obok realizacji znamion opisanych w ust. $1 \mathrm{nr} 1-3$, konieczne jest wystapienie opisanego w tym przepisie skutku. Dopóki skutek nie wystapi, może być mowa co najwyżej o usiłowaniu popełnienia oszustwa podatkowego, które jest karalne na podstawie $§ 370$ ust. 2 niemieckiej Ordynacji podatkowej ${ }^{16}$. Sprawca musi swoim zachowaniem doprowadzić do wystapienia co najmniej jednego z dwóch skutków wskazanych w $§ 370$ ust. 1, tj. do uszczuplenia podatków (Steuerverkürzung) lub do uzyskania dla siebie lub osoby trzeciej nieuzasadnionych korzyści podatkowych (nicht gerechtfertigte Steuervorteile).

Zgodnie z treścią $§ 370$ ust. 4 niemieckiej Ordynacji podatkowej do uszczuplenia podatków dochodzi w szczególności w trzech przypadkach:

1) kiedy ich wymiar nie zostaje w ogóle ustalony,

2) kiedy ich wymiar zostaje ustalony w niepełnej wysokości lub

3) kiedy ich wymiar zostaje ustalony nieterminowo, tj. w niewłaściwym czasie.

Uszczuplenie podatku to zatem przede wszystkim brak jego ustalenia lub ustalenie w zbyt niskiej wysokości, co z kolei powoduje zagrożenie wystapienia szkody majątkowej. W tym bowiem przypadku, jeżeli faktyczne świadczenie podatnika będzie ilościowo niższe niż wierzytelność państwa, państwo poniesie rzeczywistą szkodę majątkowa. Skutek w postaci uszczuplenia podatku wystapi także wtedy, gdy podatek zostanie ustalony w późniejszym terminie, niż być powinien. Zagrożenie wystapienia szkody majątkowej sprowadza się zatem w tej sytuacji do tego, że obowiązek podatkowy zrealizowany później spowoduje, że państwo straci odsetki za opóźnienie.

Drugim z możliwych skutków opisanych w $§ 370$ niemieckiej Ordynacji podatkowej jest uzyskanie dla siebie lub osoby trzeciej nieuzasadnio-

\footnotetext{
${ }^{13}$ S. Tripmaker, Verhältnis und Abgrenzung von Steuerhinterziehung und Betrug, Köln, 2010, s. 97.

${ }_{14}$ Por. uchwała BGH z 21 października 2008 r., 3 StR 420/08, wistra 2009, 60; uchwała BGH z 2 lutego 2010 r., 4 StR 345/09, uchwała BGH z 7 grudnia 2010 r., 3 StR 433/10, StV 2011, 726.

${ }_{15}$ Por. wyrok SN z 11 lutego 2003 r., IV KKN 21/00, Lex, nr 77435.

${ }^{16}$ Zgodnie z $§ 23$ ust. 1 niemieckiego k.k. usiłowanie zbrodni jest zawsze karalne, a usiłowanie występku tylko wtedy, gdy ustawa tak wyraźnie stanowi.
} 
nych korzyści podatkowych ${ }^{17}$. Korzyść podatkową sprawca uzyskuje przez korzystne (preferencyjne) rozporządzenia organu podatkowego, które nie wynikaja z deklaracji podatkowej czy ustalenia wymiaru podatku, aczkolwiek muszą być przewidziane w prawie podatkowym. Korzyściami tymi sa w szczególności zwroty podatku, na co wskazuje wyraźnie treść $§ 370$ ust. 4 zd. 2 Ordynacji podatkowej. Do korzyści podatkowych zalicza się także odroczenia terminu płatności, zawieszenie wykonania czy zwolnienia podatkowe ${ }^{18}$. Nieuzasadniona jest z kolei taka korzyść podatkowa, której podatnik nie mógłby uzyskać z uwagi na rzeczywisty brak uprzywilejowanej sytuacji faktycznej. Jeżeli korzyść podatkowa jest udzielana na podstawie zasady słuszności (tzn. kiedy właściwy organ dysponuje zakresem uznania), to będzie ona nieuzasadniona, jeżeli decyzja o jej przyznaniu oparta jest na nieprawdziwych danych ${ }^{19}$.

Zgodnie z $§ 370$ ust. 4 zd. 2 niemieckiej Ordynacji podatkowej korzyść podatkowa uchodzi za uzyskana, jeżeli została sprawcy udzielona lub pozostawiona. Według dominujaccego poglądu doktryny niemieckiej skutek w postaci uzyskania korzyści zachodzi nie wtedy, kiedy korzystne rozporządzenie ulega wykonaniu (tj. gdy dochodzi np. do wypłaty zwrotu podatku), lecz już w momencie wydania decyzji o korzystnym rozporządzeniu.

Podsumowując, należy zatem przyjać, iż przestępstwo oszustwa podatkowego w Niemczech jest, podobnie jak w Polsce, przestępstwem konkretnego narażenia na niebezpieczeństwo ${ }^{20}$.

Majac powyższe na uwadze, należy stwierdzić, że zachowania, które teoretycznie w przypadku klasycznego oszustwa (przestępstwo naruszenia dobra prawnego) wypełniałyby zarówno w prawie polskim, jak i niemieckim tylko znamiona usiłowania, na gruncie prawa karnego skarbowego mogłyby skutkować pociagnięciem do odpowiedzialności za dokonane oszustwo podatkowe.

\section{ZNAMIĘ PRZEDMIOTOWE WPROWADZENIA W BŁĄD/ WYZYSKANIA BLĘDU}

Wprowadzenie w błąd oznacza, że sprawca swoimi podstępnymi zabiegami doprowadza inną osobę do mylnego wyobrażenia o rzeczywistym stanie rzeczy. Tymczasem wyzyskanie błędu polega na wykorzystaniu przez sprawcę

${ }_{17} \mathrm{~W}$ k.k.s. zostało odrębnie unormowane przestępstwo bezpodstawnego zwrotu podatku. Zgodnie z art. $76 \S 1$ tej ustawy skutkiem ww. przestępstwa jest „narażenie na nienależny zwrot podatkowej należności publicznoprawnej, w szczególności podatku naliczonego w rozumieniu przepisów o podatku od towarów i usług, podatku akcyzowym, zwrot nadpłaty lub jej zaliczenie na poczet zaległości podatkowej lub bieżących albo przyszłych zobowiązań podatkowych”. To właśnie sformułowanie należałoby uznać za najbardziej zbliżone do skutku „uzyskania nieuzasadnionej korzyści podatkowej”, o której mowa $§ 370$ ust. 4 zd. 2 niemieckiej Ordynacji podatkowej.

${ }_{18}$ H. Kudlich, M. T. Oğlakcığlu, Wirtschaftsstrafrecht, Heidelberg-München-Landsberg-Frechen-Hamburg 2011, s. 64.

${ }_{19}$ B. Gast-de Haan, W. Joecks, R. Voss (Hrsg.), Steuerstrafrecht mit Steuerordnungswidrigkeiten und Verfahrensrecht. Kommentar §§ 369-412 AO, § 32 ZollVG, München 2001, s. 176.

20 Por. ibidem, s. 176. 
już istniejących, niezgodnych z rzeczywistościa, opinii lub wyobrażeń osoby pokrzywdzonej ${ }^{21}$.

Zgodnie z orzecznictwem niemieckim relewantne pozostaje jedynie wprowadzenie w błąd co do okoliczności faktycznych ${ }^{22}$. Przy czym za fakt w rozumieniu § 263 ust. 1 niemieckiego k.k. uznaje się nie tylko to, co rzeczywiście się zdarzyło lub zaistniało, ale także to, co tylko rzekomo miało się zdarzyć lub zaistnieć, o ile można mu przypisać cechę obiektywnej określoności i pewności ${ }^{23}$.

A zatem odpowiednikiem „czynnego” oszustwa mogłoby być podanie nieprawdy w trakcie składania organowi podatkowemu, innemu uprawnionemu organowi lub płatnikowi deklaracji lub oświadczenia z art. 56 k.k.s., a także podanie nieprawdziwych danych co do podatkowo istotnych okoliczności z § 370 ust. 1 niemieckiej Ordynacji podatkowej. Natomiast oszustwo „bierne” można by rozważać w przypadku zatajenia prawdy albo niedopełnienia obowiąku zawiadomienia o zmianie danych (prawo polskie) oraz niepoinformowania, wbrew obowiązkowi, organów podatkowych o istotnych podatkowo okolicznościach (prawo niemieckie).

$\mathrm{Na}$ gruncie oszustw podatkowych brak wyraźnego wskazania znamienia wystapienia błędu po stronie organu podatkowego. Jego uproszczonego odpowiednika można się jednak w mojej ocenie doszukać w - dającej się wyprowadzić z wykładni funkcjonalnej i systemowej - konieczności zaistnienia uprzedniej niewiedzy organu podatkowego co do faktu przedstawienia mu fałszywych/niepełnych danych. Powyższe opiera się na założeniu, że skutecznie wprowadzić w błąd można tylko taki podmiot, który nie wie, jak wygląda rzeczywisty obraz zdarzeń, tj. nie zdaje sobie sprawy, że jest wprowadzany w błąd. Niewiedza jest zatem elementem występującym na przedpolu „wprowadzenia w błąd".

$\mathrm{Na}$ gruncie prawa polskiego zagadnienie to nie jest jednoznacznie rozstrzygnięte. Z jednej bowiem strony podnosi się, że do realizacji znamion strony przedmiotowej oszustwa podatkowego wystarczające jest podanie nieprawdy lub zatajenie prawdy $\mathrm{w}$ deklaracji lub oświadczeniu, nawet jeżeli zachowanie to nie wywołuje błędu po stronie organu podatkowego, innego uprawnionego organu lub płatnika ${ }^{24}$. Z drugiej zaś - w orzecznictwie wskazuje się, iż „przestępstwo z art. $94 \S 1$ ustawy karnej skarbowej (obecnie opisane $\mathrm{w}$ art. 56 k.k.s.) stanowiło oszustwo w postępowaniu podatkowym, polegające m.in. na podaniu $\mathrm{w}$ tym postępowaniu niezgodnych $\mathrm{z}$ rzeczywistością danych, mogących mieć wpływ na ustalenie zobowiązania podatkowego. Do istoty tak opisanego działania należy umyślne wprowadzenie w błąd organu podatkowego co do rzeczywistego stanu rzeczy, istotnego z punktu widzenia prawidłowego ustalenia wysokości należnego Skarbowi Państwa podatku" (wyrok SN z 2 grudnia 2002 r., IV KKN 559/99, Lex, nr 75491).

\footnotetext{
${ }^{21}$ Por. wyrok SN z 20 lutego 1974 r., V KR 49/74, OSNKW 1974, nr 7-8, poz. 138.

${ }^{22}$ Por. uchwała BGH 6 września 2001 r., 5 StR 318/01, wistra 2002, 99.

${ }^{23}$ Por. wyrok BGH z 26 kwietnia 2001 r., 4 StR 439/00, BGHSt 47,1, wistra 2001, 255.

${ }^{24}$ Por. P. Kardas, G. Łabuda, Kryminalizacja oszustwa podatkowego w prawie karnym skarbowym, „Prokuratura i Prawo” 2003, nr 3, s. 62.
} 
W mojej ocenie, przychylając się zasadniczo do przytoczonego stanowiska Sądu Najwyższego, przestępstwo oszustwa podatkowego może popełnić tylko ten, kto wykorzystuje niewiedzę organu odnośnie do podania mu fałszywych okoliczności. Jeżeli organ podatkowy już wcześniej wiedział, że dane są nieprawdziwe, zachowanie sprawcy nie byłoby bowiem w stanie spowodować konkretnego „narażenia podatku na uszczuplenie”. Powyższe opiera się na założeniu, że jeżeli organ podatkowy zna prawdziwe okoliczności zdarzenia podatkowego, to mimo podania nieprawdy w deklaracji powinien prawidłowo ustalić wysokość podatku. Można nawet zaryzykować stwierdzenie, że błędne ustalenie wymiaru podatku, mimo wiedzy organu o rzeczywistym stanie rzeczy, nie jest spowodowane zachowaniem sprawcy składającego deklarację, lecz wadliwym postępowaniem pracownika organu.

$\mathrm{W}$ prawie niemieckim znamię pozostawienia organu podatkowego $\mathrm{w}$ niewiedzy jest wyraźnie opisane w $§ 370$ ust. $1 \mathrm{nr} 2$ Ordynacji podatkowej, który polega na sprzecznym z obowiązkiem prawnym zaniechaniu poinformowania organów podatkowych o istotnych podatkowo okolicznościach. W doktrynie niemieckiej zgodnie przyjmuje się, że chodzi tutaj pozostawienie organu finansowego w niewiedzy, pomimo możliwości i szczególnego zobowiązania do jej usunięcia. Organ podatkowy pozostaje w niewiedzy nie tylko wtedy, kiedy nieznane jest mu całe zdarzenie podatkowe, np. prowadzenie działalności gospodarczej, ale także wtedy, gdy nie zna on, np. z powodu braku zarejestrowania we właściwym czasie tej działalności, rzeczywistej wysokości dochodów z niej uzyskiwanych. Niewiedza organu co do istotnych podatkowo okoliczności nie będzie zachodzić w przypadku, gdy organ powzią informację o tych okolicznościach, lecz pochodzi ona z innego źródła niż deklaracja samego sprawcy ${ }^{25}$. Jeżeli sprawcy tylko wydaje się, że organ finansowy nie wie o istotnych podatkowo okolicznościach, w rachubę mogłoby wchodzić co najwyżej usiłowanie, które należałoby zakwalifikować jako usiłowanie nieudolne ${ }^{26}$.

W przypadku przestępstwa oszustwa podatkowego opisanego w $\S 370$ ust. $1 \mathrm{nr} 1$ niemieckiej Ordynacji podatkowej, polegającego na podaniu organowi finansowemu nieprawdziwych lub niepełnych danych co do podatkowo istotnych okoliczności, powyższe zagadnienie, z uwagi na brak w przepisie zarówno znamienia „wprowadzenia w błąd”, jak i „pozostawienia w niewiedzy” organu, długo wywoływało rozbieżności. Ostatecznie Federalny Sąd Najwyższy (Bundesgerichtshof) w uchwale z 14 grudnia 2010 r. ${ }^{27}$ uznał, że dla bytu przestępstwa z $\S 370$ ust. $1 \mathrm{nr} 1$ Ordynacji podatkowej nieistotne jest ani to, czy organ w chwili czynu posiadał już wiedzę o nieprawdziwości danych, ani to, czy zachowanie sprawcy wywołało błąd po stronie organu.

Niemniej jednak, niezależnie od ww. orzeczenia, w literaturze niemieckiej wciąż podnosi się, że konieczne jest uzupełnienie znamion oszustwa podatkowego z $§ 370$ ust. $1 \mathrm{nr} 1$ o niepisane znamię „niewiedzy organu finansowego co do nieprawdziwości/niekompletności składanych mu danych”, mających wpływ na ustalenie zobowiązania podatkowego.

\footnotetext{
25 B. Gast-de Haan, W. Joecks, R. Voss (Hrsg.), op. cit., s. 197.

26 Por. § 22 niemieckiego k.k.

27 BGH NJW 2011, 1299 f, HRRS 2011 nr. 334.
} 
Zdaniem Brigitte Hilgers przyjęcie niepisanego znamienia „niewiedzy organu finansowego" pozwala funkcjonalnie powiązać zachowanie sprawcy ze skutkiem wymaganym ustawą. Zauważa ona, że przestępstwo oszustwa podatkowego miało w założeniu skompensować niekorzystna pozycję prawna państwa jako wierzyciela, który permanentnie pozostaje w niewiedzy co do okoliczności życiowych podatników, a skutkujących powstaniem zobowiązań podatkowych. Jeżeli jednak w konkretnym przypadku organ finansowy zna prawdziwa podstawę opodatkowania, wtedy w zasadzie ww. kompensacji nie potrzebuje $^{28}$.

W doktrynie niemieckiej zauważa się także, że w prawie karnym, w tym w prawie karnym skarbowym, obowiązuje zasada subsydiarności (Grundsatz der Subsidiarität). Zarówno w przypadku klasycznego oszustwa, jak i oszustwa podatkowego ich byt uzasadniany jest m.in. bezradnością pokrzywdzonego oraz brakiem realnych możliwości samoochrony. Tymczasem organ finansowy, który wie, że dane przekazane przez podatnika są nieprawdziwe czy niekompletne, powinien potrafić sam ustrzec się oszustwa i nie potrzebuje dodatkowej prawnokarnej ochrony ${ }^{29}$.

Ponadto słusznie wskazuje Lara Herbertz, że gdyby kierować się ww. orzeczeniem Niemieckiego Sądu Najwyższego, to powstaje sprzeczność aksjologiczna pomiędzy tym, że popełnia przestępstwo ten, kto podaje niepełne dane, mimo że organ wie o niekompletności tych danych (§ 370 ust. $1 \mathrm{nr} 1$ ), a do odpowiedzialności karnej nie zostaje już pociąnnięty ten, kto w ogóle nie składa deklaracji, jeżeli organ finansowy ma wiedzę o rzeczywistym stanie rzeczy ( $\$ 370$ ust. $1 \mathrm{nr} 2)^{30}$.

Reasumując, w mojej ocenie w przypadku przestępstwa oszustwa podatkowego, stypizowanego w art. 56 polskiego k.k. oraz § 370 ust. 1 nr 1 niemieckiej Ordynacji podatkowej, nie występuje wprawdzie (inaczej niż w przypadku klasycznego oszustwa z art. 286 polskiego k.k. oraz § 263 niemieckiego k.k.) znamię strony przedmiotowej w postaci wprowadzenia w błąd organu podatkowego, ale zespoły znamion tych przestępstw - zarówno w prawie polskim, jak i niemieckim - wymagaja systemowego uzupełnienia o element „niewiedzy organu finansowego co do nieprawdziwości/niekompletności składanych mu danych”.

\section{STRONA PODMIOTOWA}

Zgodnie z wyrokiem Sądu Najwyższego z 3 lipca 2007 r. (II KK 327/06) „określone w art. $286 \mathrm{KK}$ przestępstwo oszustwa jest przestępstwem umyślnym, zaliczanym do tzw. celowościowej odmiany przestępstw kierunkowych. Ustawa wymaga, aby zachowanie sprawcy było ukierunkowane na określony cel, którym w przypadku oszustwa jest osiagnięcie korzyści majątkowej. Sprawca podejmując działanie musi mieć wyobrażenie pożądanej dla niego

${ }^{28}$ Por. B. Hilgers, op. cit., s. 96-98; L. V. Herbertz, Ist die Steuerhinterziehung ein Betrug?, „Höchstrichterliche Rechtsprechung zum Strafrecht” 13(7), 2012, s. 327.

29 Por. B. Hilgers, op. cit, s. 96-98; L. V. Herbertz, op. cit., s. 327.

${ }^{30}$ L. V. Herbertz, op. cit., s. 328. 
sytuacji, która stanowić ma rezultat jego zachowania. Powyższe ujęcie znamion strony podmiotowej wyklucza możliwość popełnienia oszustwa z zamiarem ewentualnym, zamiar bezpośredni winien obejmować zarówno cel, jak i sam sposób działania zmierzający do zrealizowania tego celu. Sprawca musi chcieć takiego właśnie sposobu działania w celu osiagnięcia korzyści majątkowej i cel ten musi stanowić punkt odniesienia każdego ze znamion przedmiotowych przestępstwa”.

Również stypizowane w $§ 263$ ust. 1 niemieckiego k.k. przestępstwo oszustwa może być popełnione wyłącznie umyślnie, w zamiarze uzyskania dla siebie lub osoby trzeciej korzyści majątkowej (Bereicherungsabsicht). Zamiar ten nie występuje m.in. wtedy, kiedy sprawca przewiduje wystapienie korzyści majątkowej jako koniecznego lub możliwego skutku swojego czynu, nakierunkowanego wyłącznie na osiagnięcie innego skutku, np. na danie pokrzywdzonemu nauczki ${ }^{31}$.

Z kolei przestępstwo oszustwa podatkowego uregulowane w art. $56 \S 1$ i 2 k.k.s. może być popełnione tylko umyślnie. Nie jest przy tym wymagane działanie w celu osiagnięcia korzyści majątkowej. Podobnie jest w przypadku oszustwa podatkowego w prawie niemieckim. Zgodnie z $§ 15$ niemieckiego k.k. karze za przestępstwo podlega tylko zachowanie umyślne, chyba że ustawa wyraźnie wskazuje, że zagrożone kara jest także zachowanie nieumyślne. Biorąc pod uwagę treść wspomnianego już § 369 ust. 2 niemieckiej Ordynacji podatkowej, należy dojść do wniosku, że przestępstwo stypizowane w $§ 370$ tej ustawy może być popełnione tylko umyślnie. Zasadniczo wystarcza już zamiar ewentualny ${ }^{32}$. Również tutaj brak konieczności działania przez sprawcę w celu uzyskania korzyści majątkowej dla siebie lub osoby trzeciej.

\section{ZBIEG PRZEPISÓW ORAZ ZBIEG PRZESTĘPSTW}

W tym miejscu, mając na uwadze przedstawione wyżej rozważania, należy przeanalizować, czy istnieje taki rodzaj zachowania sprawcy, który prowadziłby do wypełnienia znamion zarówno klasycznego przestępstwa oszustwa, jak i oszustwa podatkowego. W przypadku odpowiedzi twierdzącej należy w dalszej kolejności rozważyć, jakie relacje zachodzą między obiema normami, tj. czy jest to zbieg przepisów czy czynów zabronionych oraz czy jest on zbiegiem właściwym czy pomijalnym, niewłaściwym.

Na gruncie prawa polskiego rozważania należy rozpocząć od wskazania, iż zgodnie z art. $8 \S 1$ k.k.s.: ,jeżeli ten sam czyn będący przestępstwem skarbowym lub wykroczeniem skarbowym wyczerpuje zarazem znamiona przestępstwa lub wykroczenia określonego w przepisach karnych innej ustawy, stosuje się każdy z tych przepisów”. Wyżej wymieniony przepis kreuje idealny

31 Por. uchwała BGH z 24 maja 2011 r., 4 StR 175/11; uchwała OLG w Jenie z 27 września 2005 r., 1 Ss 259/05, „Neue Zeitschrift für Strafrecht” 2006, 450.

32 B. Gast-de Haan, W. Joecks, R. Voss (Hrsg.), op. cit., s. 236. 
zbieg czynów zabronionych. Jest to swego rodzaju fikcja prawna, aczkolwiek w jej następstwie dochodzi do skazania za dwa przestępstwa. W praktyce pojawiło się pytanie, czy reguły wyłączania wielości ocen (tj. zasada specjalności ${ }^{33}$, zasada pochłaniania ${ }^{34}$ oraz zasada subsydiarności ${ }^{35}$ ) maja zastosowanie do regulacji zawartej $\mathrm{w}$ art. 8 k.k.s. We wcześniejszym orzecznictwie zaobserwować można było dwa przeciwstawne stanowiska. Jedno sprowadza się do poglądu, że wymienione reguły stosuje się wyłącznie do zbiegu przepisów ${ }^{36}$, drugie natomiast opowiada się za możliwościa korzystania z ww. reguł także do ustalania istnienia lub nieistnienia idealnego zbiegu deliktó $w^{37}$. Obecnie kwestia ta została rozstrzygnięta uchwała składu siedmiu sędziów SN z 24 stycznia 2013 r. (I KZP 19/12), zgodnie z którą reguły wyłączania wielości ocen mają zastosowanie jedynie w wypadku zbiegu przepisów ustawy, natomiast nie stosuje się ich w razie idealnego zbiegu czynów zabronionych, o którym mowa w art. $8 \S 1$ k.k.s. W uzasadnieniu ww. uchwały SN stwierdził m.in.: „Nie ma żadnych poważnych racji natury celowościowej, które podawałyby w wątpliwość rezultaty wykładni gramatycznej i systemowej. Przeciwnie, występują argumenty, które przemawiają za koncepcją negująca możliwość stosowania reguł redukcji ocen prawnych do rozwiązania przewidzianego $\mathrm{w}$ art. $8 \S 1$ k.k.s. Trudne do zaakceptowania byłoby to, że w razie oceniania czynu wyłącznie przez pryzmat przepisów Kodeksu karnego skarbowego i ustalenia, że kwota podatku narażonego na uszczuplenie nie przekracza ustawowego progu (chodzi np. o wykroczenia skarbowe z art. $56 \S 3$ k.k.s. lub art. $76 \S 3$ k.k.s.) termin przedawnienia karalności byłby znacznie krótszy, niż dla czynu konstruowanego w płaszczyźnie art. 8 § 1 k.k.s., gdy sprawcy należałoby przypisać popełnienie zarówno wykroczenia skarbowego, jak i np. przestępstwa z art. $13 \S 1$ k.k. w zw. z art. $286 \S 1$ k.k.”. Sąd wyraźnie wskazał, iż należy wykluczyć, aby przepis k.k.s. mógł wyprzeć na zasadzie specjalności lub konsumpcji przepis k.k. (lub odwrotnie) i aby w konsekwencji doszło do skazania i wymierzenia sprawcy jednej kary.

W dalszej kolejności należy rozważyć, czy jakiekolwiek zachowanie sprawcy faktycznie wypełnia znamiona zarówno art. 56 §.k.s. oraz art. $286 \S 1$ k.k., co oznaczałoby, że sąd obowiązany byłby stosować każdy z tych przepisów (tzn. i z k.k.s., i k.k.). Należy przyjaćc, że zachowanie sprawcy polegające na obniżeniu (zaniżeniu) wysokości należnego do zapłaty podatku nie stanowi doprowadzenia do niekorzystnego rozporządzenia mieniem Skarbu Państwa lub innego

${ }^{33}$ Lex specialis derogat legi generali.

${ }^{34}$ Lex consumens derogat legi consumptae.

${ }^{35}$ Lex primaria derogat legi subsidiariae.

${ }^{36}$ Por. postanowienie SN z 8 kwietnia 2009 r., IV KK 407/08, Lex, nr 503265; wyrok SA w Łodzi z 24 marca 2009 r., II AKa 210/08, „Krakowskie Zeszyty Sądowe” 2010, z. 4, poz. 63.

${ }^{37}$ Por. uchwała SN z 30 września 2003 r., I KZP 22/03 oraz uchwała SN z 30 września 2003 r., 16/03, OSNKW 2003, z. 9-10, poz. 75 i 77; wyrok SN z 12 sierpnia 2008 r., V KK 76/08, Lex, nr 449041; wyrok SN z 19 marca 2008 r., II KK 347/07, Lex, nr 388503; wyrok SA we Wrocławiu z 3 września 2009 r., II AKa 105/09, „Krakowskie Zeszyty Sądowe” 2009, z. 12, poz. 87; wyrok SA we Wrocławiu z 31 maja 2010 r., II AKa 103/10, OSAW 2011, z. 1, poz. 209; wyrok SA w Katowicach z 13 czerwca 2011 r., II AKa 146/11, Lex, nr 1001360; wyrok SA w Katowicach z 1 czerwca 2011 r., II AKa 83/11, „Krakowskie Zeszyty Sąowe” 2011, z. 9, poz. 122; wyrok SA w Katowicach z 3 lutego 2011 r., II AKa 476/11, Lex, nr 846492. 
uprawnionego podmiotu. Tytułem przykładu zaniżenie przez sprawcę wartości przedmiotu darowizny, a tym samym należnego na podstawie samoobliczenia podatku od darowizny, skutkuje de facto zmniejszonym rozporządzeniem $\mathrm{z}$ majątku samego sprawcy/uniknięciem wydatku z własnego majątku podatnika. Nie dochodzi do żadnego rozporządzenia majątkiem Skarbu Państwa ${ }^{38}$. Skoro nie dochodzi do rozporządzenia majątkiem Skarbu Państwa lub jednostki samorządu terytorialnego, nie można mówić o wypełnieniu przez takie zachowanie sprawcy znamion przestępstwa klasycznego oszustwa.

W tym miejscu z uwagi na to, iż konstrukcja niemieckiego „oszustwa podatkowego" obejmuje de facto także zachowanie polegajace na uzyskaniu bezpodstawnego zwrotu podatkowej należności publicznoprawnej, stypizowane obecnie w prawie polskim w art. $76 \S 1$ k.k.s., należy także rozważyć, czy pomiędzy tym przepisem a art. $286 \S 1$ polskiego k.k. może występować idealny zbieg przestępstw. Wyjaśnienia wymaga, iż w art. $76 \S 1$ k.k.s., inaczej niż w art. 56 $\S 1$ k.k.s., występuje znamię „wprowadzenia w błąd właściwego organu”.

W poprzednio obowiązującym stanie prawnym, tj. na gruncie obowiązywania ustawy z 8 stycznia $1993 \mathrm{r}$. o podatku od towarów i usług oraz o podatku akcyzowym $^{39}$, SN w postanowieniu z 1 marca 2004 r. (V KK 248/03) uznał, że: „w wypadku, gdy czynności wykonawcze sprawcy wyłudzajacego nienależny zwrot podatku VAT [...] nie sprowadzaja się do zaniechania rzetelnego zgłoszenia przedmiotu opodatkowania, prowadzącego do uniknięcia wydatku z własnego mienia kosztem uszczuplenia spodziewanego dochodu finansowego Skarbu Państwa, lecz polegaja na działaniu fingującym istnienie obowiązku podatkowego - wyłącznie w celu osiagnięcia z tego tytułu korzyści z majątku Skarbu Państwa - przez upozorowanie przed organem skarbowym (przy pomocy fikcyjnych dokumentów lub przez podjęcie innych jeszcze czynności) przeprowadzenia realnej transakcji, w tym dotyczącej rzeczywiście istniejącego towaru, a nie jego substytutu, to działanie takie stanowi przestępstwo określone w przepisach Kodeksu karnego, nie zaś przestępstwo skarbowe”.

$\mathrm{Na}$ gruncie obecnie obowiązującej ustawy z 11 marca 2004 r. o podatku od towarów i usług ${ }^{40}$, w odróżnieniu od ustawy z 8 stycznia 1993 r. o podatku od towarów i usług oraz o podatku akcyzowym, fikcyjne faktury VAT, nieznajdujące odzwierciedlenia w rzeczywistych operacjach gospodarczych, rodzą jednak obowiazek podatkowy przez sam fakt ich wystawienia. Z powyższego wynika, że aktualnie rozliczenie fikcyjnej faktury VAT w celu uzyskania zwrotu podatku od towarów i usług, skoro powstało w ten sposób faktyczne zobowiązanie podatkowe, wywołuje konkretne niebezpieczeństwo uszczuplenia spodziewanego z tytułu podatku dochodu finansowego fiskusa przez uniknięcie wydatku z własnego mienia. Zatem inaczej niż w orzeczeniu SN z 1 marca 2004 r. należy uznać, iż w takiej sytuacji dochodzi do wypełnienia znamion przestępstwa skarbowego $\mathrm{z}$ art. $76 \S 1$ k.k.s.

${ }^{38}$ Por. P. Kardas, Prawnokarne aspekty uchylania się od wykonania zobowiazania podstawowego w podatku VAT - oszustwo skarbowe czy oszustwo klasyczne, „Prokuratura i Prawo” 2006, nr 5 , s. 28 i n.

${ }^{39}$ Dz. U. Nr 11, poz. 50 ze zm.

${ }^{40}$ Dz. U. 2004, Nr 54, poz. 535 ze zm. 
Przed datą uchwały składu siedmiu sędziów SN z 24 stycznia 2013 r., z uwagi na dopuszczenie stosowania reguł wielości ocen przy rozstrzyganiu istnienia lub nieistnienia idealnego zbiegu przestępstw, przyjmowano na ogół, że: „Porównanie treści art. $76 \S 1$ k.k.s. i art. $286 \S 1$ k.k. prowadzi do oczywistego wniosku, że pierwszy z nich jest przepisem lex specialis $\mathrm{w}$ stosunku do drugiego. Znamiona przestępstwa z art. $76 \S 1$ k.k.s. mieszczą się całkowicie w ogólnie ujętym przepisie działania sprawcy przestępstwa z art. $286 \S 1$ k.k., typizując szczególny rodzaj oszustwa prowadzącego do wyłudzenia nienależnego zwrotu podatkowej należności publicznoprawnej. Niczego nie zmienia $\mathrm{w}$ tej ocenie to, że w art. $76 \S 1$ k.k.s. penalizuje się już samo narażenie na nienależny zwrot podatku, co oznacza przesunięcie progu sprawstwa na zachowanie, które stanowiłoby usiłowanie popełnienia oszustwa w rozumieniu art. 286 $\S 1$ k.k. [...]. Aktualnie wystawca faktury niemającej w ogóle odzwierciedlenia w stanie faktycznym, ma także obowiązek uiszczenia podatku VAT. Zatem przepisem, który należy zastosować przy kwalifikacji prawnej czynu polegajacego na wyłudzeniu nienależnego zwrotu podatku VAT jest art. $76 \S 1$ k.k.s." (wyrok SN z 12 sierpnia 2008 r., V KK 76/2008). Jednocześnie uznawano jednak, że w wypadku, gdy „fikcyjną” fakturę VAT wystawiono wyłącznie dla przestępczych celów pozapodatkowych (np. dla doprowadzenia innej osoby do niekorzystnego rozporządzenia mieniem przez fingowanie dobrej kondycji gospodarczej i wiarygodności kontrahenta umowy), to wystawca takiej faktury lub osoba posługująca się nią powinny nadal odpowiadać na podstawie przepisów ustawy k.k., a nie k.k.s. (np. z art. $286 \S 1$ k.k.) ${ }^{41}$.

W mojej ocenie z uwagi na treść uchwały SN z 24 stycznia 2013 r. nie można dłużej przyjmować, że w przypadku wypełnienia przez sprawcę swoim zachowaniem znamion zarówno oszustwa z art. 286 k.k. (tudzież usiłowania oszustwa) oraz przestępstwa z art. 76 k.k.s. dochodzi do pomijalnego zbiegu przepisów. Wyżej wymieniona sytuacja stanowi bowiem idealny zbieg przestępstw opisany w art. 8 k.k.s., a co za tym idzie - nie można tutaj powoływać się na zasadę specjalności. Obecnie w prawie polskim całkowicie dopuszczalna prawnie jest zatem sytuacja, w której ten sam sprawca w związku z wyłudzeniem zwrotu podatku VAT, poniesie odpowiedzialność zarówno za przestępstwo oszustwa (ewentualnie usiłowanie oszustwa), jak i za przestępstwo z art. $76 \S 1$ k.k.s.

W prawie niemieckim natomiast nie ma odpowiednika art. $8 \S 1$ k.k.s. Jeżeli zatem sprawca swoim zachowaniem wypełnia znamiona zarówno przestępstwa powszechnego, jak i przestępstwa skarbowego konsekwencje prawne rozważyć należy na gruncie zbiegu przepisów ustawy, rzeczywistego bądź niewłaściwego (pomijalnego). Zgodnie $\mathrm{z}$ dominujaccym poglądem doktryny niemieckiej przestępstwo z $\S 370$ Ordynacji podatkowej wypiera na gruncie zbiegu przepisów przestępstwo klasycznego oszustwa z § 263 niemieckiego k.k. Sporne jednak pozostaje, czy oszustwo podatkowe stanowi lex specialis $\mathrm{w}$ stosunku do klasycznego oszustwa. Jeżeli bowiem zakładamy, że oszustwo podatkowe nie obejmuje wszystkich znamion przestępstwa oszustwa (a jak była mowa wyżej, brakuje tutaj znamienia „wprowadzenia w błąd” organu podatkowego), to jed-

${ }^{41}$ Por. postanowienie SA we Wrocławiu z 3 września 2009 r., II AKa 105/2009. 
nocześnie nie może być mowy o zastosowaniu zasady specjalności. Należałoby zatem raczej przyjąć, że mamy tutaj do czynienia z zasadą subsydiarności ${ }^{42}$. Wyjątkowo jedynie może dojść do rzeczywistego zbiegu przepisów, mianowicie w sytuacji, kiedy poprzez oszustwo podatkowe sprawca ma zamiar osiagnąć także inne, pozapodatkowe, korzyści majątkowe i jednocześnie jego zachowanie wypełnia wszystkie znamiona przestępstwa z § 263 niemieckiego k.k., w tym cechuje się wprowadzeniem w błąd organu podatkowego ${ }^{43}$.

\section{PODSUMOWANIE}

W podsumowaniu dotychczasowych rozważań należy podkreślić, że podstawowa systemowa różnica pomiędzy oszustwem podatkowym a klasycznym oszustwem zarówno w prawie polskim, jak i niemieckim sprowadza się do braku w przypadku tego pierwszego znamienia strony przedmiotowej w postaci „wprowadzenia w błąd". Autorka postuluje jednak, aby oba typy znamion oszustwa podatkowego, stypizowane w art. $56 \S 1$ i 2 k.k.s. oraz $\S 370$ ust. $1 \mathrm{nr} 1$ niemieckiej Ordynacji podatkowej uzupełnić - na podstawie wykładni funkcjonalnej i systemowej - o niepisane znamię „niewiedzy organu finansowego co do nieprawdziwości/niekompletności składanych mu danych". Tylko bowiem w sytuacji niewiedzy państwa może dojść do zrealizowania przez sprawcę skutku czy to w postaci narażenia podatku na uszczuplenie, czy też w postaci uszczuplenia podatków albo uzyskania dla siebie lub osoby trzeciej nieuzasadnionych korzyści podatkowych. Jeżeli bowiem organ podatkowy już wcześniej wiedział, że dane podawane przez sprawcę są nieprawdziwe, to de facto nie mogło dojść do konkretnego narażenia interesów finansowych Skarbu Państwa. Co za tym idzie - brakuje $\mathrm{w}$ takiej sytuacji wypełnienia wszystkich znamion przestępstwa materialnego, jakim jest oszustwo podatkowe zarówno w prawie polskim, jak i niemieckim.

Odnośnie do zbiegu oszustwa podatkowego tudzież wyłudzenia nienależnego zwrotu podatku z klasycznym oszustwem należy podkreślić, że w polskim prawie skarbowym występuje unikalna konstrukcja prawna idealnego zbiegu przestępstwa powszechnego z przestępstwem skarbowym, nieznana niemieckiemu prawu karno-skarbowemu. Jak słusznie zauważył SN w wyroku z 8 kwietnia 2009 r. (IV KK 407/08), ma ona uzasadnienie z punktu widzenia interesów finansowych państwa, a oprócz tego znacząco ułatwia organom finansowym egzekucję odpowiedzialności ${ }^{44}$. Na gruncie prawa polskiego mamy zatem do czynienia z równoległą odpowiedzialnością karnoskarbowa oraz karną za ten sam czyn. Nie występuje jednak tutaj pomiędzy k.k.s. a k.k. zbieg rzeczywisty przepisów, ponieważ - z uwagi na przypisanie sprawcy wię-

${ }^{42}$ Por. B. Hilgers, Täuschung, op. cit., s. 110; A. Hoff, Das Handlungsunrecht der Steuerhinterziehung, Berlin 1999, s. 28.

${ }_{43}$ A. Hoff, op. cit., s. 29.

${ }^{44}$ Por. F. Prusak, Ustawa karna skarbowa $z$ komentarzem, Warszawa 1995, s. 19. 
cej niż jednego czynu na podstawie art. 8 k.k.s. - nie znajduje zastosowania zasada, że jeden czyn stanowi tylko jedno przestępstwo ${ }^{45}$.

$\mathrm{W}$ prawie niemieckim z kolei - z uwagi na zasadę jedności czynu (Tateinheit) - sytuacja wypełnienia przez sprawcę swoim zachowaniem jednocześnie znamion § 370 niemieckiej Ordynacji podatkowej oraz § 263 niemieckiego k.k. rozstrzygana jest na gruncie zbiegu przepisów. Co do zasady oszustwo podatkowe uznawane jest za przestępstwo subsydiarne wobec klasycznego oszustwa i wypiera $\S 263$, a co za tym idzie - mamy tutaj do czynienia ze zbiegiem pomijalnym.

dr Iwona Sepioło-Jankowska

Uniwersytet im. Adama Mickiewicza w Poznaniu

isepiolo@amu.edu.pl

\section{TAX FRAUD AND A CRIME OF FRAUD UNDER POLISH AND GERMAN LAW}

Sum mary

This article deals with tax fraud under German and Polish criminal law. Under German law this crime belongs to a small group of delicts which are threatened with punishment. However, in the German legal system, tax fraud is criminalised narrowly, contrary to the Polish solution. Under Polish law there is a separate legislative act covering several dozen infringements of public finances which provides for penalisation of them all. This paper seeks to establish to what extent the features that amount to tax fraud under the Polish Criminal-Fiscal Code and German Tax Law relate to the features of a classical crime of fraud under the Polish and German criminal codes, respectively, and what are the consequences.

${ }^{45}$ Zob. uchwała (7) SN z 24 stycznia 2013 r., I KZP 19/12. 